\title{
Kontaktfamilj/kontaktperson - omfattning och samband med placering i dygnsvård
}

\author{
BO VINNERLJUNG \& EVA FRANZÉN
}

\begin{abstract}
Sedan början av 1980-talet har kontaktfamilj/kontaktperson för varje år blivit en allt vanligare barnavårdsinsats. Men kunskapsluckorna är många. I denna studie används nationella register för att undersöka insatsens omfattning $i$ olika åldersgrupper samt samband med placering-och med risk för placering-i dygnsvård.
\end{abstract}

\section{Inledning och bakgrund}

Kontaktfamilj eller kontaktperson är idag den vanligaste barnavårdsinsatsen i Sverige. Den har funnits sedan 1982, reglerad i socialtjänstlagen (SoL). Trots att kontaktfamiljer/-personer nu i 22 år har blivit utsedda som stöd till främst barn med ensamstående mammor, är kunskapen om insatsen påtagligt begränsad. Gunvor Andersson

Bo Vinnerljung är professor i socialt arbete och arbetar på Epidemiologiskt Centrum (EpC) och på Institutet för utveckling av metoder i socialt arbete (IMS), Socialstyrelsen.

Eva Franzén är fil. dr. i socialt arbete och arbetar på EpC vid Socialstyrelsen. och Maria Bangura Andersson gjorde 2001 en omfattande översikt av den forskning som finns, innefattande 18 uppsatser på C- och D-nivå från 1983 till 2000. De fann exempelvis att kontaktfamilj nästan alltid är en tvåföräldersfamilj som huvudsakligen används som insats för yngre barn. Däremot är kontaktperson oftast en man, och används främst som intervention för tonåringar. Vidare framkom att barn och ungdomar med utländsk bakgrund är underrepresenterade bland dem som får insatsen. Socialtjänstens motiv för att tillsätta en kontakfamilj/-person är oftast relaterade till att barnets pappa är frånvarande i barnets liv. I översikten konstateras också att insatsen används för många syften, bland

Bo Vinnerljung \& Eva Franzén: Kontaktfamilj/kontaktperson - omfattning och... 
annat för "avlastning» av ensamstående föräldrar men också som en "förebyggande» åtgärd (se även Johnsson \& Regnér 2003). Det framgår klart från alla undersökningar som gjorts - oavsett urvalsstorlek och kvalitet - att insatsen är populär bland föräldrar, socialarbetare och kontaktfamiljerna/-personerna själva. Alla parter är nöjda (även om de delvis anger olika motiv till att vara nöjda) och inga studier har funnit att insatsen är, eller upplevs vara, kopplad till kontrollambitioner hos Socialtjänsten (Andersson \& Bangura Arvidsson 2001). Detta kan möjligen förvåna eftersom en Stockholmsstudie från 1994 noterade att det fanns en allvarlig social problematik i drygt hälften av de familjer som fick kontaktfamilj av Stockholm stad, bland annat missbruk och psykisk sjukdom hos föräldrarna (Sundell et al. 1994, jfr Johnsson \& Regnér 2003).

Utöver dessa "konsumentstudier" vet vi nära nog ingenting om andra former av utfall, och - som Andersson \& Bangura Arvidsson (2001) konstaterar - det är svårt att avgöra vad som är rimliga kriterier och mått på utfall och effekter. Men även en rad andra kunskapsluckor identifierades av författarna. Vi vet exempelvis mycket lite om vilka samband det finns mellan kontaktfamilj/-person och dygnsvård (fosterhemseller institutionsvård). I hur hög grad är det samma barn som både får kontaktfamilj/person och som placeras i dygnsvård? Hur vanligt är det med placering $i$ dygnsvård efter att barn har haft kontaktfamilj eller kontaktperson? I artikeln redovisas två studier där vi undersökt några områden, som hittills varit obelysta i svensk forskning och statistik.

\section{Frågeställningar}

Den första studien syftar till att besvara följande frågor:

- Hur vanligt är det bland barn i Sverige att vid 6, 12 och 18 års ålder ha erfarenhet av kontaktfamilj/-person?

- Hur har denna omfattning av insatsen förändrats över tid?

- Hur vanligt är det att barn och ungdomar, som vid 6, 12 och 18 års ålder har erfarenhet av kontaktfamilj/-person, också har varit placerade i dygnsvård? Eller med andra ord: i vilken utsträckning är det samma barn som både haft kontaktfamilj/-person och varit i vård utom hemmet?

- Har sambandet ändrats över tid, det vill säga har det blivit mer eller mindre vanligt att samma barn har haft kontaktperson/-familj och varit placerade i fosterhem och/eller på institution?

I den andra studien undersöker vi samband mellan kontaktfamilj/-person och placering efter insatsen i två specifika åldersgrupper, och ställer frågorna:

- Hur vanligt är det att barn som har kontaktfamilj någon gång i 0-2 års åldern - men ej varit i dygnsvård under dessa år - placeras i dygnsvård under förskoleåren (3-7 år)?

- Hur vanligt är det att barn som haft kontaktfamilj/-person någon gång i 1012 års åldern - men ej varit i dygnsvård under dessa år - placeras i dygnsvård under tonåren (13-17 år)?

- Hur påverkar olika föräldraanknutna 
bakgrundsfaktorer inom dessa två grupper risken för placering?

- Hur stor risk löper barn i dessa grupper att placeras i dygnsvård under förskoleåren respektive tonåren jämfört med jämnåriga barn till ensamföräldrar som inte har fått insatsen vid 0-2 respektive 10-12 års ålder, och där barnet heller inte varit i dygnsvård under dessa år?

- Hur stor risk löper barn i dessa grupper att placeras i dygnsvård under förskoleåren respektive tonåren jämfört med jämnåriga barn $i$ psykosocialt utsatta familjer som inte har fått insatsen vid 0-2 respektive 10-12 års ålder, och där barnet heller inte varit i dygnsvård under dessa år?

Den åldersmässiga avgränsningen av urvalet gör det möjligt att undersöka två i ålder rejält skilda grupper, och samtidigt ha en uppföljningstid på fem år under en hyggligt "naturlig« åldersperiod under barnens uppväxt: förskoleåldern och tonåren.

\section{Metod}

\section{Datakällor och variabelkonstruktioner}

Studierna som redovisas i denna artikel bygger på uppgifter från nationella register som Socialstyrelsen och SCB ansvarar för. Uppgifter om kontaktfamiljs/-personsinsatser samt placeringar har hämtats från Registret över socialtjänstens insatser för barn och unga, även kallat "Barn/unga registret». Detta är ett personregister som förs av Socialstyrelsen för framställning av officiell statistik och för forskningsändamål. Kommunernas socialnämnder inrapporterar individbaserade uppgifter om samtliga placeringar för vård utanför hemmet enligt SoL ${ }^{1}$ och $\mathrm{LVU}^{2}$, omedelbara omhändertaganden enligt LVU samt - fram till och med 1997 - beslut om kontaktfamilj/-person. Registret har funnits sedan 1968 och har vid förändringar i lagstiftningen anpassats till nya förhållanden så långt det har varit möjligt. Uppgifterna är begränsade till enkla basuppgifter om barnet och placeringen (främst kön, lagparagraf, datum för påbörjad och avslutad placering samt om placeringen var i fosterhem eller på institution). Det innehåller inga användbara uppgifter ${ }^{3}$ om skäl för placering eller andra så kallade "baseline-data» på individnivå (varken om barnet eller föräldrarna), ej heller data om socialtjänstens tidigare överväganden eller om egenskaper hos vårdmiljön (t.ex.data om kontaktfamiljer eller fosterföräldrar).

Tillförlitligheten i registrets data är till stora delar okänd. Detta gäller både underoch överrapportering från kommunerna, även om underrapportering sannolikt är det största problemet (Sundell \& Humlesjö 1997, Vinnerljung et al. 1999, Sundell et al. 2004). Vi kan utgå från att det finns både systematiska och slumpmässiga fel. Tillförlitligheten i rapporteringen varierar mellan olika kommuner och troligen också över tid. Det innebär att vi i den första studien

1 Socialtjänstlagen

2 Lagen med särskilda bestämmelser om vård av unga.

3 Registret innehåller bara noteringar om miljö/ beteende indikation för LVU-vård.

Bo Vinnerljung \& Eva Franzén: Kontaktfamilj/kontaktperson - omfattning och... 
underskattar förekomst av erfarenhet av kontaktfamilj/-person i olika åldrar, eftersom det sannolikt finns en underrapportering av faktiska insatser. ${ }^{4}$ I den andra studien underskattar vi även förekomsten av placeringar efter påbörjad kontaktfamiljs/personsinsats, eftersom det sannolikt finns en underrapportering av påbörjade placeringar. Våra resultat ska följaktligen i dessa avseenden ses som minimisiffror.

Däremot är det mindre troligt att inrapporteringen påverkas av sådana faktorer som barnets ålder och kön eller av mammans bakgrund, vilket innebär att inrapporteringsbristerna sannolikt har en slumpmässig påverkan på de bakgrundsvariabler som vi i den andra studien arbetar med i analysen. I den har vi kombinerat data om barnen med information i en rad andra register hos SCB och Socialstyrelsen. Via Flergenerationsregistret (SCB) har vi länkat barnen med deras biologiska föräldrar. I registret finns alla personer som förekommer i folkbokföringsdata från 1961 och är födda 1932 eller senare. Vissa brister finns i registret, framförallt för personer vars föräldrar är födda utomlands (SCB 2001, Ringbäck Weitoft 2003).

I undersökningen används bara data som är direkt relaterade till mödrarna, och till deras situation när barnen var 0-2 respektive 10-12 år (kalenderåren 1990-1992). Skälet att bara använda mödrarelaterade

4 I ett stickprov från Stockholm angående insatser under hela uppväxten för barn födda 1968 - 1975, fanns knappt någon underrapportering avseende kontaktfamiljer/-personer (Sundell et al. 2004). Men ingen vet om detta gäller även yngre kohorter i Stockholms stad, hur det är i andra kommuner etc. data är att all tidigare svensk forskning om barn som har kontaktfamilj/-person liksom barn i dygnsvård (fosterhem, institution) har visat att dessa barn sällan har sammanboende föräldrar, och att fäderna vanligen har en undanskymd roll i familjens dagliga liv (t.ex. Hessle 1988, Vinnerljung 1996a, Andersson \& Bangura Arvidsson 2001). Data om mödrarna har hämtats främst från SCB's databas LOUISE, ${ }^{5}$ som består av data från Registret över totalbefolkningen (RTB), Inkomst och förmögenhetsstatistik (IoF), Utbildningsregistret, Registerbaserad arbetsmarknadsstatistik (RAMS) samt FoB 90 (Befolkningsräkningen 1990). För närmare beskrivning av LOUISE hänvisas till SCB's publikationer (SCB 2001, 2002). De data vi använt är:

- mors födelseland, indelat i två kategorier: Sverige och Norden. Vi har begränsat studiepopulationen till att enbart gälla barn till mödrar födda inom Norden av skäl som vi återkommer till senare i texten.

- mors familjeställning 31 december 1992: gift/sammanboende eller ensamboende.

- mors registrerade högsta utbildning 31 december 1992 (egentligen året före, eftersom utbildningsdata är från föregående år), här indelade i tre grupper: grundskola, gymnasium och högskola.

- utbetalt socialbidrag till mor när barnet var 0-2 år (för den yngre åldersgruppen) eller när barnet var 10-12 år (den äldre åldersgruppen). Summa utbetalt (indi-

5 LOUISE $=$ Longitudinell databas kring $u$ tbildning, inkomst och sysselsättning 
viduell andel) socialbidrag har sedan omräknats till procentandel av moderns disponibla inkomst under dessa tre år. Vi har valt att dikotomisera variabeln till $>50$ procent av den disponibla inkomsten, eller mindre. Gränsen 50 procent har satts för att särskilja familjer med mycket högt socialbidragsmottagande under en period av tre år.

Vi har dessutom använt data om sjukhusvård för missbruk och psykiatriska diagnoser, inklusive självmordsförsök, någon gång när barnen var 0-2 eller 10-12 år för att få indikatorer på allvarligt missbruk eller allvarlig psykisk sjuklighet hos mamman. Data har hämtats från Socialstyrelsens Patientregister. Detta baseras på uppgifter som årligen lämnas av landstingen, och innehåller data om utskrivningar från inneliggande vård på sjukhus med upp till sju vårddiagnoser (ej om poliklinisk eller dagbehandling). Eftersom de flesta med missbruk eller psykisk sjuklighet behandlas i öppenvård (eller inte alls i sjukvården), är omfattningen av noteringar i registret långt ifrån det samma som omfattningen av dessa problem i en population. Däremot kan antas att registret ger en stark indikation på förekomst av mycket svåra problem. Vårddiagnoserna baseras på den ansvarige läkarens bedömning och innehåller därför ett visst mått av subjektivitet (Ringbäck Weitoft 2003). Bortfall och felaktiga uppgifter bedöms dock vara ett litet problem när uppgifterna agregeras (a a). Vi har använt tre kategorier av diagnoser $i$ analysen, grupperade enligt den nionde versionen av WHO's internationella klassifikation (ICD-9):
- Alkoholrelaterad diagnoser (alk): huvud- eller bidragande diagnos ICD 291, 303, 305:0, 357:5, 425:5, 535:3 eller 571:1-571:4.

- Narkotikarelaterad diagnos (nark): huvud- eller bidragande diagnos ICD 292, 304, 965:0, 968:5 eller 969:5969:7.

- Annan psykiatrisk diagnos, inklusive självmordsförsök (psyk): ICD 293-302, 306-319.

I analysen slås dessa tre diagnoskategorier samman i en dikotom variabel: alk/nark/ psyk, det vill säga förekomst i minst en av kategorierna eller ej.

\section{Jämförelsegrupper}

I syfte att tentativt jämföra risken för placering efter kontaktfamiljs/-personinsats med andra gruppers risk för placering, har vi med hjälp av registerdata konstruerat tre jämförelsegrupper bestående av barn från samma födelsekohorter som undersökningsgruppen (1990-1992 respektive 19801982), varav de två senare är att betrakta som högriskgrupper:

\section{Barn med ensamstående föräldrar.} Urvalskriterium är att barnets förälder är registrerat som ensamstående i LOUISE 1992. Dessutom ska barnet inte ha haft kontaktfamilj/-person eller varit placerad i dygnsvård mellan 0 2 års ålder eller 10-12 års ålder. Såväl svenska som utländska studier har visat att barn till ensamstående föräldrar löper en förhöjd risk att pla- 
ceras i dygnsvård jämfört med barn i två-föräldershushåll (Bebbington \& Miles 1989, Höglund Davila \& Landgren-Möller 1991, Egelund \& Hestbaek 2003 m.fl.). Alla studier av kontaktfamiljs/-personsinsatsen visar att barn till ensamstående föräldrar dominerar stort bland insatsmottagarna.

2. Barn med mammor som vårdats på sjukhus med en diagnos om missbruk, psykisk sjukdom eller självmordsförsök någon gång när barnet var 0-2 år eller 10-12 år (Barn med mödrar som vårdats för alk/nark/psyk). Barnet ska dessutom ej ha haft kontaktfamilj/person eller varit placerad i dygnsvård vid 0-2 eller 10-12 års ålder. Studier av fosterhems- eller barnhemspopulationer och av mindre missbrukarpopulationer tyder på att barn med denna föräldrabakgrund löper mycket hög risk att hamna i dygnsvård, även om det idag saknas större nordiska befolkningsstudier på området (översikt i Vinnerljung 1996a).

3. Barn med mammor som haft socialbidrag motsvarande minst 50 procent av den disponibla inkomsten när barnet var 0-2 eller 10-12 år (Barn med mödrar som mottagit mycket socialbidrag). Som tidigare ska barnet ej ha haft kontaktfamilj/-person och ska inte varit placerad i dygnsvård dessa år. Preliminära resultat från en pågående svensk befolkningsstudie visar på mycket starka samband mellan högt socialbidragsmottagande hos svenskfödda föräldrar och placeringar i dygnsvård av deras barn (Ringbäck Weitoft, kommande). Även internationella undersökningar har funnit förhöjda risker för barn till socialbidragstagare (t.ex. Bebbington \& Miles 1989). Här finns också skälet till att vi begränsat studien till enbart barn med svensk- eller nordiskfödda mammor. Om alla barn i landet inkluderats, oavsett moderns födelseland, hade jämförelsegrupp 3 dominerats av barn till gifta/samboende mödrar födda utanför Norden (cirka 70\%). Det verkar rimligt att anta att dessa mödrars höga socialbidragstagande är kopplat främst till flykting/invandringsbakgrund och mindre till sociala problem i familjen. Denna kategori var däremot underrepresenterad bland barn som fått kontaktfamilj/-person.

Observera att de tre jämförelsegrupperna inte är ömsesidigt uteslutande, utan överlappar delvis varandra. De utgör tre möjliga konstruktioner av jämförelsegrupp, skapade från nationella registerdata. Vi provade också möjligheten att konstruera en extrem jämförelsegrupp genom att kombinera grupp 2 och 3: barn till mödrar som vårdats på sjukhus med alk/nark/ psyk-diagnos och som samtidigt hade ett högt socialbidragstagande, men fann att gruppen blev alltför liten för våra analysbehov.

\section{Analysmetoder}

I den första studien undersöks hur vanligt det är i befolkningen att vid viss ålder ha erfa- 
renhet av kontaktfamilj/-person, hur vanligt det är att samtidigt ha erfarenhet av placering i dygnsvård (fråga 2) samt förändringar över tid i dessa avseenden. Vi har helt enkelt räknat antalet individer i viss ålder som ett givet år har haft sådana erfarenheter enligt Barn/unga-registret, och sedan jämfört dessa tal med kohortuppdelad befolkningsstatistik för aktuella år (levererad av SCB).

I den andra studien undersöks vilka föräldraanknutna bakgrundsvariabler som har påverkat risken för placering, när övriga variabler hålls konstanta, inom de två grupper som haft kontaktfamilj/-person. Detta sker i två logistiska regressionsanalyser, en för varje åldersgrupp (för beskrivning och diskussion av analysmetoden se t.ex. Tabachnick \& Fidell 1996, Vinnerljung, Sallnäs \& Kyhle Westermark 2001, Social Rapport 2001, bilaga). Resultaten redovisas med p-värden och oddskvoter $(\mathrm{OR}=$ odds ratio). ${ }^{6}$ De oberoende variabler som ingår $\mathrm{i}$ analysen är:

6 Om p exempelvis är $<0,001$, säger detta oss att det är mindre än en chans på tusen att variabelns påverkan på utfallsvariabeln (placering $\mathrm{i}$ dygnsvård)är slumpartad. OR säger hur mycket "risken" ökar för placering om faktorn förekommer jämfört med om den inte förekommer. Men OR är en punktskattning. Det 95-procentiga konfidensintervallet $(95 \% \mathrm{CI})$ redovisar inom vilket intervall OR befinner sig med 95 procent säkerhet. I stora urval blir nästan alla avvikelser statistiskt signifikanta eftersom p-värdet till stor del är en funktion av urvalets storlek. Det är därför mindre meningsfullt att enbart se till p-värdet (Achen 1986, Ravndal 1993), utan det är istället oddskvotens storlek som är av primärt intresse för oss (Ribe 1999, Gambrill \& Shlonsky 2000, Lagerberg \& Sundelin 2000, Vinnerljung et al. 2001).
- barnets kön

- barnets ålder (kontinuerlig variabel)

- mammans familjeställning (ensamstående eller gift/sambo)

- mammans födelseland (Sverige eller annat nordiskt land)

- mammans utbildning (grundskola, gymnasium eller högskola)

- förekomst av sjukhusvård med alk/nark/ psykdiagnos eller ej för mamman

- förekomst av högt socialbidragstagande eller ej ( $>50 \%$ av disponibel inkomst) under tre år för mamman

När vi jämför risken för placering av barn som fått kontaktfamilj/-person med risken i våra jämförelsegrupper använder vi samma analysmetod och samma bakgrundsvariabler. Resultaten summeras i en tabell med fyra modeller, där olika bakgrundsvariabler successivt förs in i analysen (Tabell 4).

\section{Resultat 1: omfattning}

I Diagram 1-3 redovisas hur vanligt det under 1990-1997 har varit att barn i olika åldrar har haft kontaktfamilj/-person någon gång under sitt liv.

Diagram 1 visar att det mellan 1990 och 1997 blev allt vanligare bland 6-åringar att någon haft kontaktfamilj. 1990 hade drygt en procent haft kontaktfamilj jämfört med 1,7 procent sex år senare. Den relativa ökningen över tid är betydande, runt 50 procent. Andelen som också har varit placerade varierar mellan 18 och 25 procent utan en konsistent trend över tid.

Även bland landets 12-åringar ökade andelen som haft kontaktfamilj/-person

Bo Vinnerljung \& Eva Franzén: Kontaktfamilj/kontaktperson - omfattning och... 


\section{Diagram I.}

Andel (\%) 6-åringar i befolkningen som haft kontaktfamilj (KF) under förskoleåren (0-6).

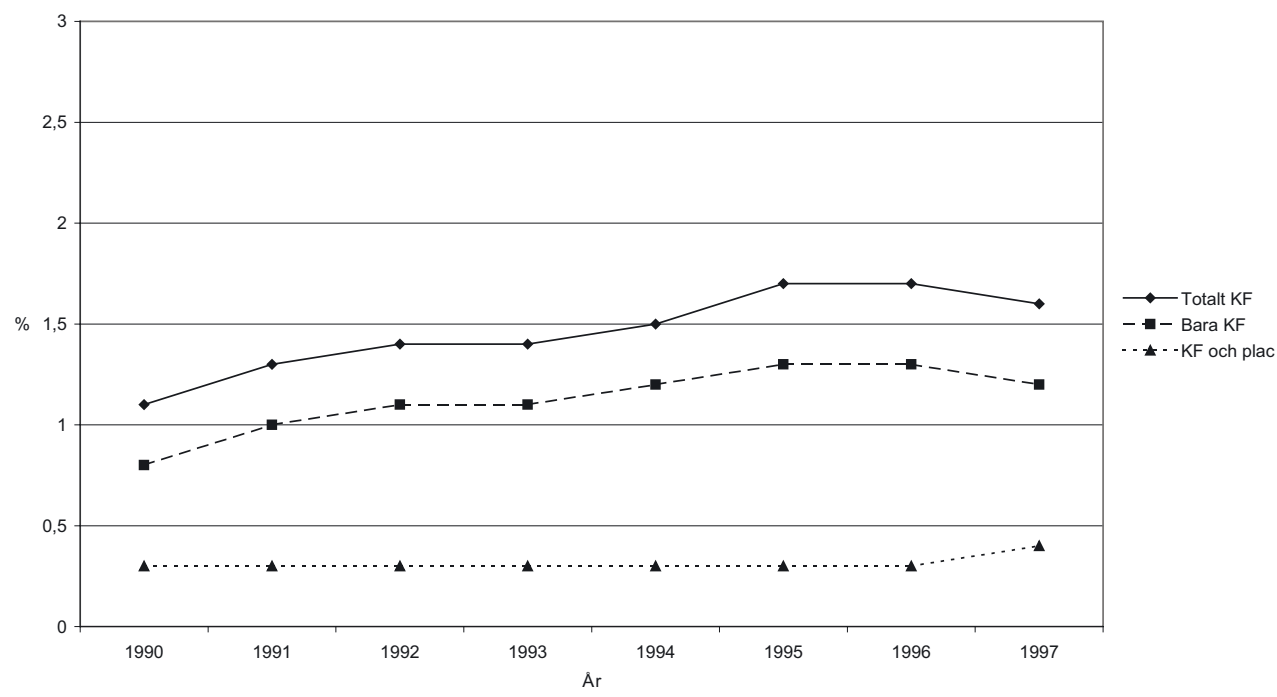

\section{Diagram 2.}

Andel (\%) 12-åringar i befolkningen som haft kontaktfamilj (KF) eller kontaktperson före tonåren (0-12 år).

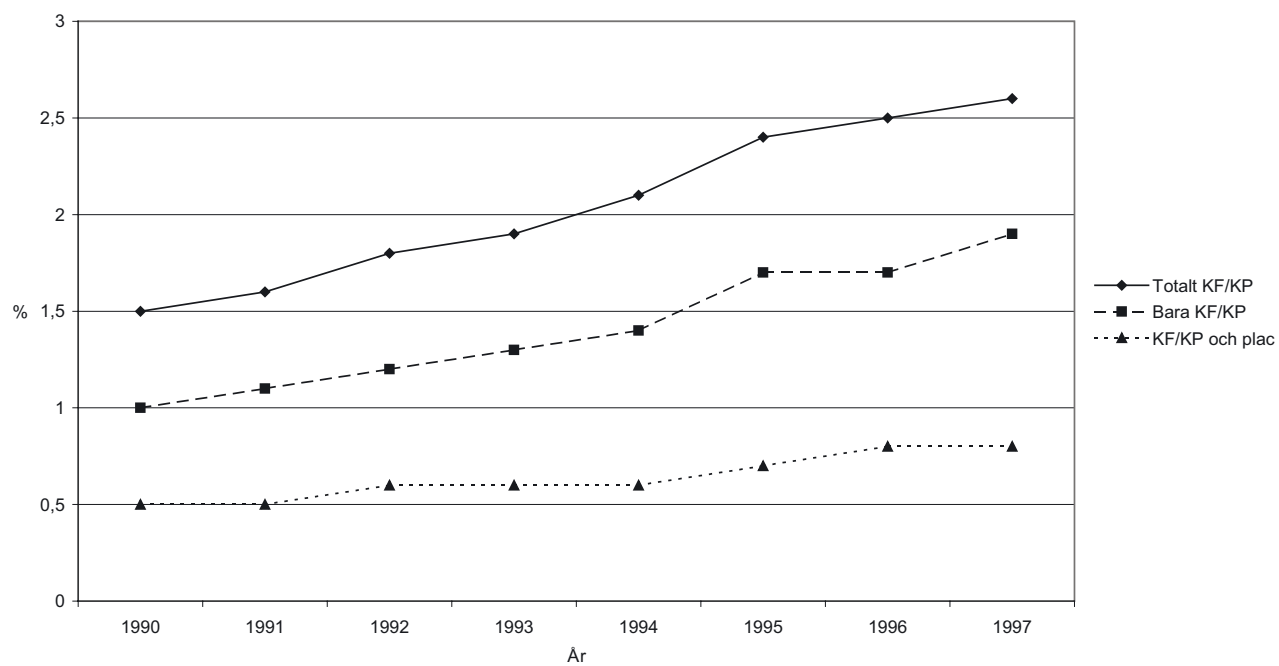

Socialvetenskaplig tidskrift $\mathrm{nr} 4 \cdot 2005$ 
kraftigt, från 1,5 procent 1990 till 2,6 procent 1997. Det innebär en relativ ökning på 73 procent. Andelen som också varit placerade ligger stabilt på 30-33 procent alla åtta åren.

I Diagram 3 ser vi att nästan tre procent av alla 18-åringar i landet 1997 hade haft kontaktfamilj/-person någon gång under sin uppväxt, runt en i varje skolklass. Jämfört med $1990(1,5 \%)$ har andelen nästan fördubblats på åtta år. Mellan 41 och 47 procent av dessa hade också någon gång $\mathrm{i}$ sitt liv varit på institution eller i fosterhem.

Sammanfattningsvis är ökningen betydande $i$ alla åldersgrupper. Om mönstret vi har sett här inte ändrades radikalt efter 1997, 7 hade i början av 2000-talet runt 3,5

7 Sista året då kontaktfamilj/-person registrerades nationellt på individnivå. procent av alla 18-åringar haft kontaktfamilj/-person någon gång under uppväxten. Däremot har andelen med erfarenhet av både kontaktfamilj/-person och placering varit stabil över tid $i$ alla tre åldersgrupper som undersökts.

\section{Resultat 2: risk för placering \\ Beskrivning av studiepopulationen}

I Tabell 1 beskrivs undersöknings- och jämförelsegrupperna. I alla kolummer har barn födda 1980-1982 och 1990-1992 slagits samman.

Av Tabell 1 framgår bland annat att pojkarna är något fler i undersökningsgruppen än i de tre jämförelsegrupperna.

\section{Diagram 3.}

Andel (\%) 18-åringar i befolkningen som haft kontaktfamilj (KF) eller kontaktperson före vuxen ålder (0-17 år).

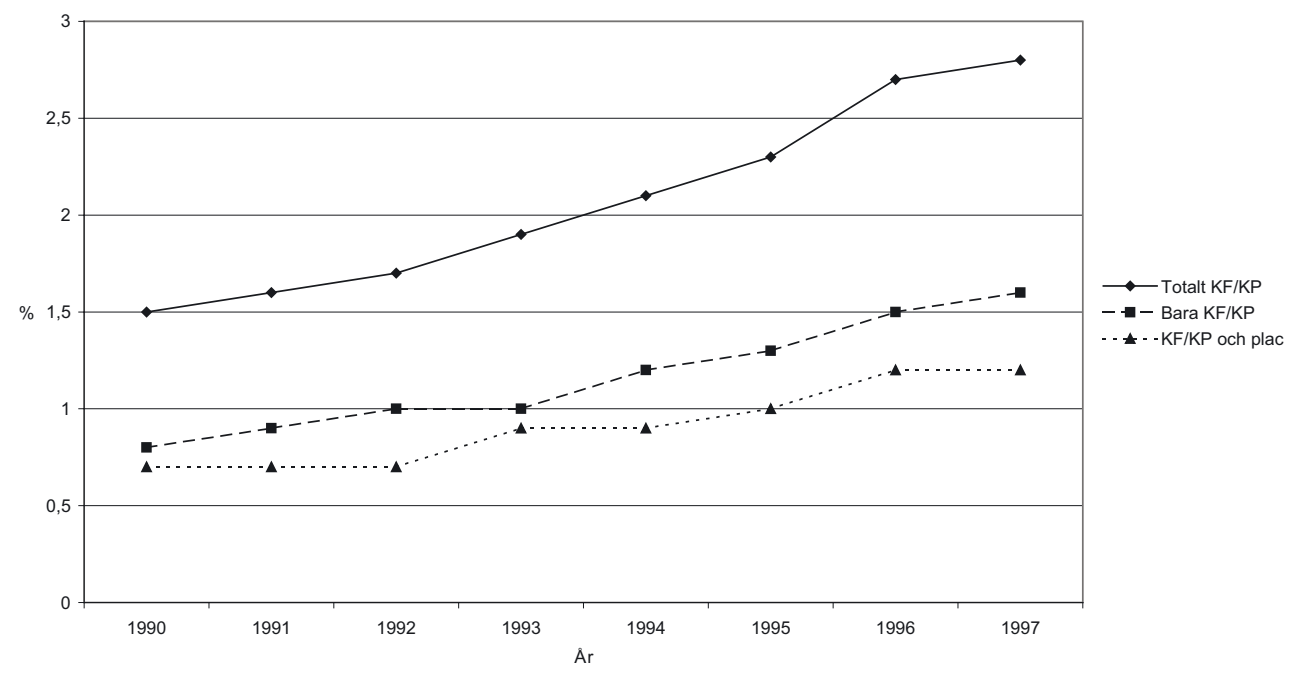

Bo Vinnerljung \& Eva Franzén: Kontaktfamilj/kontaktperson - omfattning och... 
Det är betydligt färre barn i vår studie som haft kontaktfamilj i späd ålder (0-2 år, $35 \%)$ än i förpuberteten (10-12 år, 65\%). Drygt 70 procent av undersökningsgruppens barn hade en mor som var ensamstående, medan motsvarande gällde bara 29 procent bland barnen med en mamma som vårdats på sjukhus för alk/nark/psyk. Kontaktfamiljs/-personsbarnen hade vanligen en lågutbildad mamma, bara nio procent av mödrarna hade en högskoleutbildning. Mammorna i gruppen "barn till ensamstående mödrar" och i alk/nark/ psyk-gruppen var betydligt bättre utbildade. Däremot domineras socialbidragsgruppen av mammor med bara grundskoleutbildning (61\%).

\section{Hurmånga blev placerade i dygnsvård under uppföljningstiden?}

I Tabell 2 visas hur stor andel av undersöknings- och jämförelsegrupperna som blev placerade i dygnsvård under den femåriga uppföljningstiden efter påbörjad kontaktfamiljs/-personsinsats, visad efter åldersgrupp.

Bland barnen som haft kontaktfamilj/person när de var 0-2 år blev 16 procent placerade $\mathrm{i}$ dygnsvård någon gång under förskoleåren. I gruppen som haft samma insats under förpuberteten kom 21 procent i dygnsvård under tonåren, drygt vart femte barn. Andelarna är nära nog de dubbla jämfört med barn till mammor som mottagit mycket socialbidrag (9 respektive $11 \%$ ). Färre i gruppen barn till alk/nark/psyk-vårdade mammor mötte samma öde under uppföljningstiden, sex och åtta procent. Andelen placerade barn var naturligt nog lägst i gruppen "barn till ensamstående mödrar", (2 respektive $3 \%$ ).

\section{Riskför placering inom undersökningsgruppen}

I Tabell 3 visas resultat från två logistiska regressionsanalyser av hur olika bakgrundsvariabler statistiskt påverkar risken för placering inom undersökningsgruppen, när övriga variabler hålls konstanta. Samma analys görs separat för den yngre och den äldre åldersgruppen .

Samma mönster uppträder i båda grupperna, även om osäkerhetsmarginalen för flera samband är betydande på grund av små undergrupper (breda 95-procentiga konfidensintervall). Högre utbildning hos mamman minskar risken för placering medan mycket socialbidrag under tre år eller sjukhusvård för alk/nark/psyk ökar risken. I den yngre åldersgruppen (barn 0-2 år) handlar det om en nästan trefaldig risk $(\mathrm{OR}=2,7)$ för barn till mammor som mottagit mycket socialbidrag under tre år. Exempel från bivariatanalyser: i den yngre åldersgruppen kom 34 procent i dygnsvård under uppföljningstiden om mamman mottagit mycket socialbidrag under flera år, jämfört med 13 procent bland övriga kontaktfamiljsbarn. I den äldre åldersgruppen var motsvarande siffror 35 respektive 20 procent. $^{8}$

8 Redovisas ej i tabellform. 


\section{Risk för placering jämfört med jämförelsegrupperna}

Så här långt har redovisningen begränsats till att analysera vilka faktorer inom undersökningsgruppen som ökar sannolikheten till att ett barn placeras i dygnsvård inom fem år efter kontaktfamiljsinsatsen. Dessa resultat leder fram till frågan om huruvida dessa faktorer även framstår som viktiga när vi undersöker risken för placering $i$ förhållande till våra tre jämförelsegrupper. Avsikten är således att försöka klargöra om risken för placering, i statistisk mening, kan förklaras av att de olika grupperna skiljer sig åt vad gäller sådana aspekter som ålder, utbildning etc. I regressionsmodellerna får vi möjlighet att skatta styrkan av olika samband. I Tabell 4 presenteras resultaten från 24 multivariata analyser, där vi undersöker betydelsen av de olika variablerna stegvis. I modell 1 relateras risken för placering endast till barnets kön och ålder. I den andra modellen kontrollerar vi även för moderns familjeställning och i modell 3 undersöker vi huruvida moderns utbildning och födelseland kan relateras till barnets placering. Slutligen i modell 4 läggs ytterligare två variabler in i modellerna, och konstanthålls i analysen: a) om modern vårdats på sjukhus med missbruks- eller psykiatrisk diagnos, samt b) om modern under tre år mottagit mycket socialbidrag. I jämförelsen med barn till mammor som vårats med alk/ nark/psyk-diagnos utelämnas a) i modellen, eftersom jämförelsegruppen valts utifrån att alla uppfyller detta kriterium. Samma gäller socialbidragsvariabeln i jämförelsen med barn till mödrar som mottagit mycket socialbidrag.
Resultat summeras i Tabell 4, och är förvånansvärt entydiga (samtliga OR-tal i tabellen är statistiskt signifikanta). I den yngre åldersgruppen har barn som fått kontaktfamiljsinsats när de var 0-2 år 6-10 gånger högre risk att placeras efter insatsen (under förskoleåren) jämfört med barn till ensamstående föräldrar - oavsett vilka bakgrundsfaktorer som vi justerar resultaten för. Samma undersökningsgrupp har grovt sett en dubbel överrisk för placering när de jämförs med barn till mammor som vårdats för alk/nark/psyk och med barn till mammor som mottagit mycket socialbidrag under flera år, återigen oavsett vilka bakgrundsvariabler som ingår i den logistiska regressionsanalysen.

I den äldre undersökningsgruppen är resultaten ungefär de samma som för de yngre barnen: 6-9 gånger högre risk för placering under tonåren jämfört med barn till ensamstående föräldrar och 2-4 gånger högre risk jämfört med barnen i de båda andra jämförelsegrupperna. Igen ser vi att oddskvoterna bara svagt tenderar att sjunka, när modellen i flera steg justeras för ytterligare bakgrundsfaktorer.

\section{Diskussion}

Studierna som presenterats är såvitt vi vet de första i sitt slag. Resultaten representerar ny kunskap om både omfattning av insatsen och om statistiska samband mellan kontaktfamilj/-person och placering i dygnsvård.

Bo Vinnerljung \& Eva Franzén: Kontaktfamilj/kontaktperson - omfattning och... 


\section{Tabell I}

Procentuell fördelning av egenskaper $i$ undersökningsgruppen och i jämförelsegrupperna.

\begin{tabular}{|c|c|c|c|c|}
\hline & $\begin{array}{c}\text { Barn med } \\
\text { Kont familj/ } \\
\text { person } \\
\text { n=3 } 485\end{array}$ & $\begin{array}{c}\text { Barn med } \\
\text { ensamst } \\
\text { mödrar } \\
n=73763\end{array}$ & $\begin{array}{c}\text { Barn med } \\
\text { mödrar som } \\
\text { vårdats för } \\
\text { alk/nark/psyk } \\
n=4469\end{array}$ & $\begin{array}{c}\text { Barn med } \\
\text { mödrar som } \\
\text { fătt mycket } \\
\text { socialbidrag } \\
n=3678\end{array}$ \\
\hline \multicolumn{5}{|l|}{ Barnets kön } \\
\hline pojke & 54,5 & 50,9 & 52,3 & 52,6 \\
\hline flicka & 45,4 & 49,1 & 47,6 & 47,4 \\
\hline \multicolumn{5}{|l|}{ Barnets ålder } \\
\hline $0-2$ år & 34,8 & 43,4 & 40,8 & 71,7 \\
\hline 10-12 år & 65,2 & 56,6 & 59,2 & 28,3 \\
\hline \multicolumn{5}{|l|}{ Mors familjetyp } \\
\hline Sammanboende & 25,7 & - & 61,0 & 36,2 \\
\hline Ensamstående & 71,3 & 100,0 & 28,8 & 54,6 \\
\hline Övr inkl uppgift saknas & 3,0 & - & 10,2 & 9,2 \\
\hline \multicolumn{5}{|l|}{ Mors utbildning } \\
\hline Grundskola & 40,5 & 27,7 & 29,9 & 61,4 \\
\hline Gymnasium & 48,8 & 52,1 & 48,8 & 31,6 \\
\hline Eftergymnasial & 8,9 & 20,1 & 17,8 & 3,4 \\
\hline Uppgift saknas & 1,8 & $<0,1$ & ।,5 & 3,6 \\
\hline \multicolumn{5}{|l|}{ Mors födelseland } \\
\hline Sverige & 89,6 & 92,3 & 91,5 & 85,2 \\
\hline Norden & 10,4 & 7,7 & 8,5 & 14,8 \\
\hline \multicolumn{5}{|l|}{ Mor sjukhusvård 90-92 } \\
\hline Psyk & 6,3 & 1,5 & 87,8 & 3,5 \\
\hline Alk & 2,1 & 0,3 & 16,0 & 2,2 \\
\hline Nark & 0,3 & 0,1 & 4,2 & 1,1 \\
\hline $\begin{array}{l}\text { Mor socialbidrag > 50\% } \\
\text { av disponibel ink } 90-92\end{array}$ & 5,8 & 2,6 & 4,4 & 100,0 \\
\hline
\end{tabular}




\section{Tabell 2}

Andel i procent som blivit placerade i dygnsvård under den 5 åriga uppföljningstiden, efter undersöknings- respektive jämförelsegrupp samt åldersgrupp.

\begin{tabular}{lcccc}
\hline Åldersgrupp & $\begin{array}{c}\text { Barn med } \\
\text { kontakt- familj/- } \\
\text { person } \\
\mathbf{n = 3} \mathbf{4 8 5}\end{array}$ & $\begin{array}{c}\text { Barn med } \\
\text { ensamstående } \\
\text { mödrar } \\
\mathbf{n = 7 3} \mathbf{7 6 3}\end{array}$ & $\begin{array}{c}\text { Barn med } \\
\text { mödrar som } \\
\text { vårdats för } \\
\text { alk/nark/psyk } \\
\mathbf{n = 4 4 6 9}\end{array}$ & $\begin{array}{c}\text { Barn med } \\
\text { mödrar som } \\
\text { fătt mycket } \\
\text { socialbidrag } \\
\mathbf{n = 3 ~ 6 7 8}\end{array}$ \\
\hline $0-2 \mathrm{a} r$ & 15,5 & 2,2 & 6,3 & 8,9 \\
$10-12 \mathrm{a} r$ & 21,1 & 3,4 & 7,6 & 10,7 \\
\hline
\end{tabular}

\section{Tabell 3}

Bakgrundsvariablers samband med placering $i$ dygnsvaird under uppö̈ljningstiden av barn som haft kontaktfamilj/-person. Resultat frän logistisk regressionsanalys, efter åldersgrupp. $N=1196$ (0-2 år) och $n=2223$ (10-12 år).

\begin{tabular}{|c|c|c|c|}
\hline I & $\mathbf{p}$ & $\operatorname{Exp}(B) / O R$ & $95 \% \mathrm{Cl}$ \\
\hline \multicolumn{4}{|l|}{ Kont familj 0-2 år $(n=1$ | 96): } \\
\hline Barnet en flicka & is & 1,0 & $0,7-1,4$ \\
\hline Mor ensamförälder & is & 1,1 & $0,8-1,5$ \\
\hline Mor född i annat nordiskt land & is & 0,8 & $0,5-1,5$ \\
\hline \multicolumn{4}{|l|}{ Mors utbildning: } \\
\hline Eftergymn utb vs grundskola & * & 0,5 & $0,2-1,0$ \\
\hline Gymn utb vs grundskola & ****** & 0,5 & $0,3-0,7$ \\
\hline Mor vårdad för Alk/nark/psyk & * & 1,9 & $1,1-3,2$ \\
\hline Mor mycket soc bidrag & ****** & 2,7 & $1,7-4,2$ \\
\hline Intercept & **** & & \\
\hline
\end{tabular}

Kontaktfamiljj-person 10-12 år ( $n=2223)$ :

\begin{tabular}{lccc}
\hline Barnet en flicka & is & 1,2 & $1,0-1,5$ \\
Mor ensamförälder & is & 1,0 & $0,8-1,3$ \\
Mor född i annat nordiskt land & is & 1,1 & $0,8-1,6$ \\
Mors utbildning: & & & \\
Eftergymn utb vs grundskola & $* * *$ & 0,4 & $0,3-0,6$ \\
Gymn utb vs grundskola & $*$ & 0,8 & $0,6-0,9$ \\
Mor vårdad för alk/nark/psyk & $* * *$ & 1,8 & $1,3-2,6$ \\
Mormycket socialbidrag & $* *$ & 1,8 & $1,2-2,9$ \\
\hline Intercept & $* * *$ & & \\
\hline
\end{tabular}

is = icke signifikant ${ }^{*} \mathrm{p}<0,05{ }^{* *} \mathrm{p}<0,01{ }^{* * *} \mathrm{p}<0,001$

Bo Vinnerljung \& Eva Franzén: Kontaktfamilj/kontaktperson - omfattning och... 


\section{Tabell 4}

Summering av logistiska regressionsanalyser av placering under uppföljningstiden. Barn med kontaktfamilj/-person jämfört med tre jämförelsegrupper.

\begin{tabular}{|c|c|c|c|c|}
\hline & $\begin{array}{l}\text { Modell I } \\
\text { OR/95\% Cl }\end{array}$ & $\begin{array}{l}\text { Modell } 2 \\
\text { OR/95\% Cl }\end{array}$ & $\begin{array}{l}\text { Modell } 3 \\
\text { OR/95\% Cl }\end{array}$ & $\begin{array}{l}\text { Modell } 4 \\
\text { OR/95\% Cl }\end{array}$ \\
\hline \multicolumn{5}{|l|}{$\begin{array}{l}\text { Barn med ensamstående mödrar } \\
O R=1\end{array}$} \\
\hline Kontakt fam 0-2 år & $8,0(6,7-9,5)$ & $8,3(6,7-10,2)$ & $7,1(5,7-8,7)$ & $6,9(5,6-8,5)$ \\
\hline Kontakt fam/-person 10-12 år & $7,6(6,8-8,5)$ & $7,6(6,7-8,7)$ & $6,8(6,0-7,8)$ & $6,7(5,9-7,6)$ \\
\hline \multicolumn{5}{|l|}{$\begin{array}{l}\text { Barn med mödrar som vårdats för } \\
\text { alk/nark/psyk } O R=1\end{array}$} \\
\hline Kontakt fam 0-2 år & $2,8(2,2-3,5)$ & $2,0(1,5-2,7)$ & $1,9(1,4-2,4)$ & $1,8(1,4-2,4)$ \\
\hline Kontakt fam/-person 10-12 år & $3,3(2,7-3,9)$ & $3,1(2,5-3,7)$ & $2,9(2,4-3,5)$ & $2,9(2,4-3,6)$ \\
\hline \multicolumn{5}{|l|}{$\begin{array}{l}\text { Barn med mödrar som fätt mycket } \\
\text { socialbidrag } O R=1\end{array}$} \\
\hline Kontakt fam 0-2 år & $1,8(1,5-2,2)$ & $1,8(1,5-2,2)$ & $2,0(1,7-2,5)$ & $2,0(1,6-2,5)$ \\
\hline Kontakt fam/-person $10-12$ år & $2,3(1,8-2,8)$ & $2,2(1,7-2,8)$ & $2,4(1,9-3,0)$ & $2,4(1,9-3,0)$ \\
\hline \multicolumn{5}{|c|}{$\begin{array}{l}\text { Modell 1: justerat för barnets kön } \\
\text { Modell 2: justerat för barnets kön och familjetyp } \\
\text { Modell 3: justerat för barnets kön, familjetyp, mors utbildning och födelseland } \\
\text { Modell 4: justerat för barnets kön, familjetyp, mors utbildning och födelseland, om mor vårdats för alk/ } \\
\text { nark/psyk (ingår ej i jämförelsen med barn vars mödrar vårdats för alk/nark/psyk) och om mor fått social- } \\
\text { bidrag motsvarande } \geq 50 \% \text { av disponibel inkomst (ingår ej i jämförelsen med barn vars mödrar fătt mycket } \\
\text { socialbidrag). }\end{array}$} \\
\hline
\end{tabular}

\section{Summering}

För det första kan vi se att det idag inte är ovanligt bland barn och ungdomar i Sverige att ha haft kontaktfamilj/-person någon gång under upp växten. Bland dagens 17åringar är andelen troligen cirka 3,5 procent (snarare mer än mindre), det vill säga i snitt ett barn i varje skolklass. Ökningen 19901997 var betydande i alla åldersgrupper. Bland 17-åringarna nära nog fördubblades andelen under åtta år.
För det andra har andelen barn/ungdomar som har erfarenhet av både kontaktfamilj/-person och placering i dygnsvård varit relativt stabil i alla åldersgrupper under de åtta åren som undersökts. Sambandet kan på riksnivå grovt uttryckas i tre tumregler:

- var femte sexåring som har haft kontaktfamilj har också varit placerad i fosterhem eller på institution

- samma gäller var tredje tolvåring

- vid myndighetsdagen har nästan varan- 
nan, som någon gång under sin uppväxt haft kontaktfamilj/-person, också varit placerad i dygnsvård.

För det tredje fann vi att 16 procent av alla barn som hade kontaktfamilj när de var mycket små - 0-2 år - hamnade i dygnsvård efteråt under förskoleåren. 21 procent av de som hade kontaktfamilj/-person under förpuberteten (10-12 år) placerades också i fosterhem eller på institution någon gång $\mathrm{i}$ tonåren. Motsvarande procentandelar var avsevärt lägre i våra jämförelsegrupper. Bland barn till ensamstående föräldrar handlade det om två respektive tre procent, bland barn till mammor som vårdats på sjukhus med alk/nark/psyk-diagnos var det sex respektive åtta procent och bland barn till mammor som fått mycket socialbidrag under flera år kom nio respektive elva procent i dygnsvård under samma åldersperiod.

För det fjärde: bland barn som haft kontaktfamilj/-person var det barn med lågutbildade, psykiskt sjuka/missbrukande och socialbidragsberoende mammor som löpte störst risk att hamna i dygnsvård efter insatsen. I gruppen barn till mammor som mottagit mycket socialbidrag under flera år - och som haft kontaktfamilj/-person handlade det om vart tredje barn eller mer.

För det femte fann vi att barn (i de åldersgrupper som undersöktes) som fătt kontaktfamilj/-person

- hade en 6-10 gånger högre risk att placeras i dygnsvård jämfört med barn till ensamstående föräldrar, oavsett vilka bakgrundsvariabler som konstanthölls i analysen. Överrisken var med andra ord stabil, och påverkades inte nämnvärt av de bakgrundsvariabler som ingick i våra modeller (främst socioekonomiska variabler samt vård på sjukhus för alk/nark/ psyk hos mamman).

- hade en (grovt räknat) två- trefaldig överrisk för placering i båda åldersgrupperna, jämfört med barn vars mammor hade vårdats på sjukhus med alk/nark/ psyk-diagnos eller barn vars mammor hade fått mycket socialbidrag under flera år. Igen, överrisken påverkades lite av vilka bakgrundsvariabler som ingick i modellerna. Dessa två jämförelsegrupper kan rimligen betraktas som högriskgrupper.

\section{Om insatsens omfattning och samband med placering $i$ dygnsvaird}

Angående insatsens omfattning kan vi konstatera att det idag sannolikt är minst lika vanligt bland ungdomar i befolkningen att ha erfarenhet av kontaktfamilj som att ha varit placerad i dygnsvård. Kohortstudier har visat att 3-3,5 procent i varje kohort någon gång under uppväxten har varit placerade i fosterhem eller på institution (Vinnerljung 1996b, Vinnerljung et al. 2000, Lundström \& Vinnerljung 2001). Men denna grupp verkar inte ha minskat över tid (Lundström \& Vinnerljung 2001). Däremot har omfattningen av kontaktfamiljs/-personsinsatsen ökat kraftigt.

Sambandet mellan kontaktfamilj/-person och dygnsvård har tidigare dokumenterats av Lundström \& Vinnerljung (2001) på kommunnivå. De fann att kommuner där många barn hade kontaktfamilj/-person också hade

Bo Vinnerljung \& Eva Franzén: Kontaktfamilj/kontaktperson - omfattning och... 
många placerade barn. Sambandet på individnivå framgår tydligt i denna studie. Dels hade en stor andel (knappt 50\%) av ungdomar med erfarenhet av kontaktfamilj/person också varit placerade någon gång under uppväxten, dels var det många i de åldersgrupper som vi undersökte som blev placerade åren efter de fått kontaktfamilj/person (16/21\%). Flera undersökningar har dokumenterat att det finns en betydande rundgång i det svenska barnavårdssystemet. Samma barn tenderar att återkomma till socialtjänsten efter avslutade insatser och efter hemflyttningar från fosterhemseller institutionsvård. Ofta följer insats på insats i långa kedjor (Sundell et al. 2004, Vinnerljung et al. 2004).

\section{Om riskför placering efter insats}

Risken för placering i vår undersökningsgrupp var - som förväntat - störst för barn till de sämst ställda mödrarna. Men dessa samband var knappt urskiljbara i jämförelsen med barn till ensamstående föräldrar, vilket är ganska anmärkningsvärt. Utländska studier har funnit starka samband mellan placering $\mathrm{i}$ dygnsvård av barn och föräldrars socioekonomiska bakgrund (Bebbington \& Miles 1990, Lindsey 1991, 1992, Jones 1998). I en svensk studie, baserad på ett stort nationellt kohorturval, undersöktes riskfaktorer för återplacering av barn som återvänt hem från fosterhem (Vinnerljung et al. 2004). Socioekonomiska faktorer hade ett relativt svagt förklaringsvärde avseende vilka barn som återplaceras i dygnsvård och vilka som inte gör det. Det är möjligt att det finns kontextberoende förklaringar till dessa skillnader mellan Sverige och USA respektive Storbritannien. Det svenska generella välfärdssystemet kan ha inneburit att i Sverige är det mer faktorer på individ- och familjenivå som styr barns och föräldrars öde i barnavården. Mycket tyder exempelvis på att interaktionen mellan föräldrar och myndighet har en avgörande betydelse (t.ex. Håkansson \& Stavne 1983, Andersson 1984, Sundell \& Egelund 2001) och att det ofta handlar om ansamlingar av problemfaktorer i de familjer som får sina barn omhändertagna (t.ex. Hessle 1988, Andersson 1995). Men här finns mycket att göra innan vi kan dra några säkra slutsatser. Framförallt behöver vi kohortstudier på befolkningsnivå om vilka faktorer som har starka samband med socialtjänstens insatser. Det är hög tid för replikeringar och utvecklingar av Eiwor Höglund Davilas och Elisabeth LandgrenMöllers svenska pionjärarbete på området (1991).

\section{Förebyggande insats?}

Gould, brittisk betraktare av det svenska socialtjänsten, menade att kontaktfamiljer var en billig och effektiv preventiv insats (Gould 1988, jfr Barth 1991). Men vad är det som insatsen ska förebygga? Gunvor Andersson (1992, 1993) har diskuterat detta ingående. Hon menar att kontaktfamiljs/-personsinsatsen riktas till familjer som redan har av socialtjänsten identifierade problem. Den syftar till att förhindra att problemen blir värre och till att undvika allvarligare ingripanden, det vill säga place- 
ringar i fosterhem eller på institution. ${ }^{9} \mathrm{Gör}$ kontaktfamilj/-person detta? Vi har sett att runt vart sjätte yngre barn (16\%) som fick insatsen hamnade i dygnsvård under förskoleåren och att samma hände vart femte barn (21\%) som fick insatsen i förpuberteten. Är det många eller få? Det vet vi inte, eftersom vi inte har en adekvat jämförelsegrupp för utvärderingssyften. De grupper som vi konstruerat utifrån registerdata säger oss bara att placeringsrisken är hög för kontaktfamiljs/-personsbarn, även i jämförelse med två högriskgrupper. Men vi vet inte någonting om hur det hade gått för vår undersökningsgrupp om de inte fått insatsen. Vår undersökning är inte en utvärdering.

Barn med kontaktfamilj/-person är dessutom en heterogen population, där vissa beslutade insatser snarast har karaktären av service/stöd till ensamma mammor, medan andra har mer "förebyggande» mål, exempelvis att förhindra en befarad framtida placering (Andersson \& Bangura Arvidsson 2001, Johnsson \& Regnér 2003). När insatsen har som (uttalat eller outtalat) mål att förebygga vård utom hemmet menar vi att placering efter insatsen är ett rimligt utfallsmått. Det blir orimligt att hävda motsatsen.

\section{Implikationer för praktiken}

Resultaten har - trots sina begränsningar

9 Andersson (1992) konstaterar att i både Sverige och Norge är förebyggande barnavårdsarbete det som förebygger barns placering utanför det egna hemmet. i utvärderingshänseende - ett par matnyttiga lärdomar. För det första har vi belagt att barn som får kontaktfamilj/-person definitivt är en högriskgrupp för framtida placering i dygnsvård. En kommun som har X antal pågående insatser kan räkna med att 15-20 procent av dessa barn i en snar framtid kommer att hamna i dygnsvård, om våra resultat är generaliserbara till alla åldersgrupper. Vidare visar resultaten att risken för placering är avsevärt högre bland barn till de sämst ställda mammorna, framförallt mammor som mottar mycket socialbidrag under flera år. I denna undergrupp kom drygt var tredje barn i fosterhems- eller institutionsvård under uppföljningstiden.

Slutligen pekar våra resultat också på behovet av en utvärdering av insatsen med andra utfallskriterier än upplevd tillfredsställelse hos berörda parter. Om insatsen har som syfte att förebygga omhändertagande, är förekomst av omhändertaganden efter insats ett bra och empiriskt lätthanterligt utfallsmått. Bäst vore att använda en randomiserad ansats i en sådan utvärdering (t.ex. Boruch 1997). Men det är troligen inte möjligt, eftersom kontaktfamilj/-person är en lagreglerad form av bistånd. Då återstår olika varianter av kvasiexperimentell design där man på lokal nivå försöker finna jämförbara grupper, där några fått kontaktfamilj/person och andra inte (föräldrar och/eller barn har kanske tackat nej till ett sådant erbjudande, de har kanske fått andra insatser osv.). Sådana studier vore (enligt vår bedömning) möjliga att genomföra i varje större kommun, alternativt i flera mindre kommuner som samarbetar i en gemensam utvärdering. Alternativet är att fortsätta på samma sätt som vi gjort i många år: vi

Bo Vinnerljung \& Eva Franzén: Kontaktfamilj/kontaktperson - omfattning och... 
konstaterar då och då att det är fler och fler som får kontaktfamilj/-person, men vi vet mycket lite om utfall förutom att alla är nöjda.
Författarna riktar ett varmt tack till Maria Öman, statistiker på Socialstyrelsen, för värdefull hiälp med studien.

\section{Referenser}

Achen, C. (1986) Interpreting and using regression ( $6^{\text {th }}$ printing). Beverly Hills, Ca: Sage i Applications in the Social Sciences no 29.

Andersson, G. (1984) Småbarn påbarnhem. Akad avhandl. Malmö: Liber Förlag/CWK Gleerup.

Andersson, G. (1992) Stöd och avlastning. Om insatsen kontaktperson/-familj. Lund: Meddelanden från Socialhögskolan 1992:2.

Andersson, G. (1993) "Support and relief: the Swedish contact person and contact family program». Scandinavian Journal of Social Welfare, 2, s. 54-62.

Andersson, G. (1995) Barn i samhällsvård. Lund: Studentlitteratur.

Andersson, G. \& Bangura Arvidsson M. (2001) Vad vet vi om insatsen kontaktperson/-familj? En kunskapsöversikt. Lund: Medelanden från Socialhögskolan 2001:1.

Barth, R. (1991) "Sweden's contact family program. Informal help bolsters vulnerable families". Public Welfare, 49, s. 36-46.

Bebbington, A. \& Miles J. (1989). »The background of children who enter local authority care». British Journal of Social Work, 19, s. 349-368.

Boruch, R. (1997) Randomized experiments for planning and evaluation. A practical guide. Applied Social Research Methods series, vol 44. Thousand Oaks, Ca: Sage Publ Inc.

Egelund, T. \& Hestbaek, A-D. (2003) Anbringelse af börn og unge uden for hjemmet. En forskningsoversigt. Köpenhamn: Socialforskningsinistuttet.

Gambrill, E. \& Shlonsky (2000) "Risk assessment in context". Children and Youth Services Review, 22, s. 813-837.
Gould, A. (1988) Conflict and control in welfare policy. The Swedish example. London: Longman House.

Hessle, S. (1988) Familjer i sönderfall. Göteborg: Norstedts.

Håkansson, H. \& Stavne, K. (1983) Jag känner mig så himla osäker... Stockholm: Skeab Förlag.

Höglund, Davila E. \& Landgren-Möller, E. (1991) "Vilka barn omhändertas av samhället»? I Qvist, J. (red.) Livsförloppsanalys. Stockholm: SCB, Bakgrundsmaterial från demografiska funktionen, 1991:2.

Johnsson, L. \& Regnér, M. (2003) Ensamma föräldrar och vanliga familjer. En studie av insatsen kontaktfamilj inom socialtjänsten. Göteborg: Göteborgs Universitet, Inst för socialt arbete, Skriftserien 2003:8.

Jones, L. (1998) "The social and family correlates of successful reunification of children in foster care». Children and Youth Services Review, 20, s. 305-323.

Lagerberg , D. \& Sundelin, C. (2000) Risk och prognos $i$ socialt arbete med barn. Forskningsmetoder och resultat. Stockhom: Gothia/CUS.

Lindsey, D. (1991) „Factors affecting the foster care placement decision: an analysis of national survey dataw. American Journal of Orthopsychiatry, 61, s. 272-281.

Lindsey, D. (1992) "Adequacy of income and the foster care placement decision: using an odds ratio approach to examine client variables». Social Work Research \& Abstracts, 28, s. 29-36.

Lundström, T. \& Vinnerljung, B. (2001) "Omhändertaganden av barn under 1990-talet». I Szebehely M (red.) Välfärdstjänster i omvandling. 
Antologi från Kommittén Välfärdsbokslut, SOU 2001:52.

Ravndal, E. (1993) Virker behandling? En oversikt over behandlingsresultatet för stoffmissbrukere $i$ Norden och internasjonalt. Olso: Nordmark 1993:1.

Ribe, M. (1999) „Oddskvoter berättar». Välfärdsbullentinen, 4, s. 14-15.

Ringbäck Weitoft, G. (2003) Lone parenting, socioeconomic conditions and severe ill-health - a longitudninal register-based approach. Akad. Avhandl: Umeå University Medical Dissertations, New series no. 828. EPC/Umeå Universitet.

Ringbäck Weitoft, G. (kommande) Health and social adjustment in families with long-term social assistance dependency.

SCB (2001) En longitudinell databas kring utbildning, inkomst och sysselsättning 1990-1998 - LOUISE. Örebro: SCB, Bakgrundsfakta till arbetsmarknads- och utbildningsstatistiken 2001:2.

SCB (2002) En longitudinell databas kring utbildning, inkomst och sysselsättning 1990-1998 - LOUISE. Örebro: SCB, Bakgrundsfakta till arbetsmarknads- och utbildningsstatistiken 2002:2.

Social rapport (2001) Stockholm: Socialstyrelsen, EpC.

Sundell, K. \& Egelund, T. (2001) Barnavårdsutredningar: en kunskapsöversikt. Stockholm: Gothia/CUS.

Sundell, K. \& Humlesjö, E. (1997) Den dokumenterade barnavården 1990 och 1996 i två social distrikt. Stockholm: Socialtjänsten, FoU-byrån, FoU-rapport 1997:23.

Sundell K, Humlesjö E \& Carlsson M (1994) Att hjälpa sin nästa. En undersökning av kontaktfa- miljer i Stockholm. Stockholm: Socialtjänsten, FoU-byrån, FoU-rapport 1994:15.

Sundell K, Vinnerljung B, Andrée Löfholm C \& Humlesjö E (2004) Socialtjänstens barn. Stockholm: Socialtjänsten, FoU-byrån, FoU-rapport 2004:4.

Tabachnick, B. \& Fidell, L. (1996) Using multivariate statistics. $3^{\text {rd }}$ ed. New York: Harper Collins College Publ.

Vinnerljung, B. (1996a) Svensk forskning om fosterbarnsvård. En översikt. Stockholm: Liber Utbildning/CUS.

Vinnerljung, B. (1996b) Hur vanligt är det att ha varit fosterbarn? Socialvetenskaplig Tidskrift, 3, s. 166-179.

Vinnerljung B, Hjern A \& Öman M (2004) "Återplaceringar av barn i dygnsvård: II - vad ökar eller minskar risken«?. Socialvetenskaplig Tidskrift, 11, s. 150-167.

Vinnerljung B, Langlet P, Zaar A. K, \& Gunnarson $\mathrm{T}$ (2000) „Prevalens av långa vårdtider m.m. bland barn som placerats i dygnsvård - en kohortstudie». I SOU 2000:77: Omhändertagen. Samhällets ansvar för utsatta barn och unga. Betänkande av LVU-utredningen. Stockholm: Socialdepartementet.

Vinnerljung B, Sallnäs M \& Kyhle-Westermark P (2001) Sammanbrott vid tonårsplaceringar - om ungdomar i fosterhem och på institution. Stockholm: Socialstyrelsen/CUS.

Vinnerljung B, Sallnäs M \& Oscarsson L (1999) "Dygnsvård för barn och ungdom 1983-1995». Socionomens Forskningssupplement, $\mathrm{nr} 11$ (Socionomen 8/1999), s. 1-20.

Vinnerljung B, Öman M \& Gunnarson T (2004) "Återplaceringar av barn i dygnsvård: I - hur vanligt är det». Socialvetenskaplig Tidskrift, 11, s. 54-75.

Bo Vinnerljung \& Eva Franzén: Kontaktfamilj/kontaktperson - omfattning och... 


\section{Summary}

\section{The Swedish contact family/contact person programme Prevalence at age 6/12/18 and relation to out-of-home care}

The Swedish contact family/contact person programme has existed since 1982, providing children in vulnerable or "at-risk" families with volunteer support and respite care (see Barth, 1991; Andersson, 1993 for descriptions). Consumer studies have consistently shown high satisfaction among recipients, social workers and volunteers. But otherwise knowledge of outcome is weak. In this study, we used national registers to assess:

1 The prevalence of experience in the Swedish population of the intervention at age 6,12 and at age of majority (18 years) for the years 1990-1997, also looking at changes over time.

2 The prevalence of experience of contact family/contact person and placement in out-of-home care at age 6/12/18 during 1990-1997, also examining changes over time.

In a second study, we examined risk of placement in out-of-home care after intervention for all children in the country born 1990-1992 who had a contact family/contact person at age $0-2$, and all children born 1980-1982 who had a contact family at age 10-12 $(\mathrm{n}=3,485)$. The follow-up time was five years. Logistic regression analysis was used to examine what background variables were associated with increased risk of placement within this group. We also used logistic regression models (adjusting for maternal socio-economic background variables and hospitalization of mothers for substance abuse, psychiatric illness or suicide attempt) to compare the risk of placement in the study population with three groups of cohort peers:

- children with single parents $(n=73,763)$

- children with mothers who received hospital treatment for substance abuse, psychiatric illness or for suicide attempts when their children were age $0-2$ or $10-12(n=4,469)$

- children whose mothers received substantial amounts of social welfare assistance when children were $0-2$ or 10-12 years old: $>50 \%$ of net income during three years $(n=3,678)$.

In 1997, 1.7\% of all 6-year-olds had experience of the contact family programme, at $2.6 \%$ of all 12 -year-olds and close to $3 \%$ of all 18-year-olds (today the figure is probably at least 3.5\%). Between 1990 and 1997, rates increased by $50 \%$ for the youngest group, by around $75 \%$ at age 12 and almost doubled for the 18-year-olds. In all age groups, rates of experience of both contact family/contact person and out-of-home care were stable for 1990-1997: 20\% at age $6,33 \%$ at age 12 and around $45 \%$ at age 18 .

Among the children who received the intervention at age $0-2,16 \%$ were placed in out-of-home care during follow-up. In the older group (intervention at age 
10-12), 21\% came into care during their teens. Logistic regression analysis showed increased risks of placement after intervention in both age groups when mothers had only basic education, had received hospital treatment for substance abuse, psychiatric illness or suicide attempts, or had received substantial amounts of social welfare assistance.

Compared to peers with single mothers, children in the contact family/contact person programme had seven- to eightfold elevated risks of placement. When compared to peers whose mothers had received hospital treatment for substance abuse, psychiatric illness or suicide attempts (a high-risk group), our study population had two- to threefold excess risks. Finally, in comparison to peer children whose mot- hers had received substantial amounts of social welfare (another high-risk group), we found a twofold excess risk of placement. Odds-ratios in all comparisons were only marginally affected by adjustments for background variables.

Irrespective of issues of causality, results clearly show that children in the contact family/contact person programme are a high-risk group for placement in out-ofhome care. Results cannot serve as an evaluation, since the study lacks an adequate comparison group for this purpose. But they illustrate the need for evaluation studies, using placement in out-of-home care as outcome measure. At present no evaluations have been performed during the 22 years the programme has existed, except for consumer studies. 